Gendering Pastoral Power: Masculinity, Affective Labour and Competitive Bonds of Solidarity among Filipino Migrant Men in Saudi Arabia.

Mark Johnson

Department of Anthropology

Goldsmiths, University of London

This is an Accepted Manuscript of an article published on-line by Taylor \& Francis in Gender, Place and Culture on 7 November, 2015, and available online:

http://www.tandfonline.com/doi/pdf/10.1080/0966369X.2015.1090411

Mark Johnson (2015): Gendering pastoral power: masculinity, affective labour and competitive bonds of solidarity among Filipino migrant men in Saudi Arabia, Gender, Place \& Culture, DOI: 10.1080/0966369X.2015.1090411 


\title{
Gendering Pastoral Power: Masculinity, Affective Labour and Competitive Bonds of Solidarity among Filipino Migrant Men in Saudi Arabia.
}

\author{
This article draws on Foucault's concept of pastoral power to understand Filipino \\ men's care work and the making of migrant masculinities in Saudi Arabia. Feminist \\ scholars have indicated the gendered nature of pastoral power and emphasised what \\ Young (2003) refers to as the 'logic of masculinist protection' that characterizes the \\ contemporary security state. However, the notion of pastoral power invites further \\ consideration of the taken for granted cultural assumptions about the way that \\ hegemonic masculinity and forms of homosociality are characterized mainly by \\ aggression, competition and dominance. Men's talk about and practical involvement in \\ assisting fellow migrants in diasporic settings foregrounds the way that an ethics of \\ care runs up against and is entangled with the competitive bonds of masculine \\ solidarities. While markers of material success are privileged in measuring migrant \\ men's accomplishments in country of origin, practices of care become central to men's \\ achievement of symbolic power and social legitimacy especially among their peers in \\ the diaspora. That spatialization is also linked to temporally shifting models of \\ masculinity and normative expectations about men over the life course.
}

Key Words: Masculinity; Migration; Pastoral Power; Care; Affective Labour

\section{Introduction: Gendering pastoral power}

Foucault $(2007,125)$ introduces pastoral power, defined as 'care over a flock in its movement from one place to another', to illuminate the paradox of governmentality concerned with both care and control. In a feminist critique of the United States' 'homeland security', Young (2003) draws on Foucault's notion of 'pastoral power' to describe the state sponsored 'patriarchal bargain' (Kandiyoti 1988, Steihm 1982) in which dependent men and women 
offer up their freedom and autonomy in exchange for state protection from external threat (see also Messner 2007, Jiwani 2009, Babül 2015). In this article, I bracket partially the 'masculinist logic' of the security state to extend Young's observation that the model of pastoral power also illuminates important components of men's subjectivities whose hegemonic forms have come to be understood as aggressive, competitive and domineering in opposition to women's putatively compliant, caring and submissive position and subjectivities (Connell and Messerschmidt 2005).

The context for exploring masculinity and pastoral power derives from ethnographic encounters with Filipino migrant men in Saudi Arabia. Existing scholarship shows that Filipino migrant men experience a diminishment of occupational and gender status (Margold 1995, Aguilar 1996, Haile and Siegmann 2014). However, as with other groups, the situation rarely maps out in terms of simple movement from the occupation of pre-migrant hegemonic masculinity to a subordinate and/or oppositional masculinity in destination country (Ahmad 2011, del Aguila 2013, Kathiravelu 2012, McIlwaine 2010, S McKay 2007, 2011, McKay and Lucero-Prisno 2012, Filippo and Caroline Osella 2000). Rather, it is evident that a multiplicity of temporal processes (Robinson and Hockey 2011) and spatial relations (Berg and Longhurst 2003, McIlwaine 2010) shape men's mobilities and changing social positions and subjectivities over a life course. These may result in a perceived diminishment of masculinity but may also, in Inhorn and Wentzel's terms (2011), lead to novel articulations of dominant and discrepant masculinities.

This article is concerned with the remaking of masculinities in a context in Saudi Arabia that is overtly patriarchal while foreclosing many of the routes through which migrant men can vie for dominant masculine status among men in host society. Rather than internalize a subordinate or oppositional form of masculinity, migrant men redraw the boundaries of the community of men who matter, and redefine the criteria on which the most 
excellent form of masculinity among that group of men is to be measured in that place. To anticipate the argument developed ethnographically below, while masculinity is realized daily through demonstrating the capacity to provide for their family, public recognition as an exceptional man among the community of Filipino men in this diasporic context is primarily achieved through care for one's kababayaan (compatriots).

I am not the first to observe that care is a feature of migrant men's masculinity. Filippo Osella's (2012) work on male homosocialities across the Indian Ocean discloses the changing shape of care, its channelling into publically recognizable forms of 'social work' at home associated with middle class respectability and the increasing displacement of same sex intimacies into putatively secret spaces. Kathirevelu's (2012) documents the way low waged South Asian migrant men in Dubai create 'a set of networks, relationships, logics and acts that express solidarities and connections in everyday informal interactions' $(2012,106)$. Ahmad $(2011,168)$ writing about forms of male homosocialities among recent Pakistani migrants to Europe describes how they, 'Cooked and cared for, mothered and fathered one another in the absence of friends, relatives and loved ones'.

Extending that work I make four major points about migrant men's practices of care in Saudi Arabia, which following Foucault I call pastoral power. The first is that the gendering of pastoral power as masculine is a corollary of the policing of public and private spheres in Saudi Arabia that constrain women's civic participation among both citizens and foreign residents, though as elsewhere that is shaped also by age, class and, closely associated with that, co-residence with spouse and children (see McIllwaine and Bermudez 2011). Second, the pastoral power taken on and exercised by Filipino migrant men emerges as a practical response to the precarity that some migrants experience as a result of the withholding of state welfare and regulation in a neo-liberal migration regime that is institutionalised in the kafala system of migrant visa sponsorship (Johnson and Wilcke 2015). 
The third point is that men's care for and about people they deem themselves to be ethically responsible for, is not simply that of 'care commanders', i.e. public facing and organizational, leaving the real hands on work to women as 'care footsoldiers' (Lynch, Baker and Lyons 2009). Recent work on masculinity and care, especially on (grand)fatherhood, complicates considerably stereotypes about men's incapacity and/or refusals to engage in caring practices (Doucet 2006, Hanlon 2012, Tarrant 2013). However, men are still generally deemed to be positioned at one end of a continuum from care-ful to care-less, from private to public, from intimate to faceless and from female to male, with men 'free-riders' on others, mainly women's care work (Lynch and Hanlon 2011, 47). The practices of pastoral care I describe below are, to adapt Boris and Parreñas (2010), clearly forms of intimate, affective and embodied labour that challenge those Eurocentric ways of construing gendered relations of care.

Finally, in thinking about the formation of 'caring masculinities' (Elliot 2015) it is important not to assume that care is counterpoised to power and domination even if practices of care shift significantly the ways that dominant status is achieved and recognized. That is, while care is the royal road to masculinity among this group of migrant men, as Bourdieu (1990) suggests in another context, the recognition received by the virtuous stands in inverse relation to recognitions sought; that is, to be recognized, care must be given in such a way that it is not deemed to be self-seeking but rather sacrificial, a labour of love. In that way, pastoral power is certainly defined by beneficence, but it is still a form of power whose efficacy resides precisely in the ability to solicit signs of recognition through gentle and sometimes tender acts of care giving.

\section{Situating Migrant Filipino Men in Saudi Arabia.}

The inspiration for attending to men's acts of care derives from my late colleague Alicia 
Pingol's (2001) seminal study of contemporary masculinity in the Philippines that detailed subtle shifts in the caring practices of men with migrant wives. Alicia Pingol and I conducted ethnographic research in Saudi Arabia and the Philippines as part of a project on migrant Filipinos in the Middle East (Johnson and Werbner 2010): Pingol in Madinah, Jeddah and Riyadh between September 2007 and January 2008 and Johnson mainly in Riyadh in AprilMay 2009. Research in the Philippines was interspersed within those periods. The research involved participant observation and informal conversation with a range of women and men in a variety of settings who were living or had previously lived and worked in the Kingdom supplemented by targeted interviews with migrant domestic workers whose movements in Saudi Arabia are constrained in ways that limit opportunities for more informal encounters (Johnson and Wilcke 2015).

There are more than one million Filipinos living in Saudi Arabia. Many live in the Kingdom for long periods as part of an incipient diaspora (Weiner 1986) without permanent residency or citizenship rights. As elsewhere in the region, migrant Filipinos in Saudi Arabia are subject to a visa sponsorship system that grants citizen-employers substantial power over migrant employees and ensures that the host government shoulders minimal responsibility for their welfare (A. Gardner 2010). The consequences of that sponsorship system vary significantly according to race, class and gender positions.

In terms of land based migrant Filipinos, Saudi Arabia remains one of the few destinations where men still outnumber women (approximately 55\% to 45\%) and occupationally is one of the most diverse, making class a significant feature of migrant life in that place (Johnson 2010). Religion too is an important differentiating factor. For Filipino Muslims, Saudi Arabia is the birthplace of Islam and an important pilgrimage destination. While identification as a Muslim rarely entails social privilege it is not generally deemed to be a source of discrimination as it is perceived to be by Muslims in the majority Christian 
Philippines. Filipino Muslims, like their Christian counterparts, generally considered race, class and gender to be as significant as religious affiliation in terms of the social hierarchies encountered.

That raced, classed, gendered and religious dynamic shapes people's work and living experiences including forms of sociality and civic participation. Formal political participation in Saudi Arabia is non-existent, for foreign residents as for most citizens, and forms of civic participation are circumscribed by prohibitions on trade unions and regulations that constrain voluntary associations, including church based organizations that figure prominently elsewhere (Johnson and Werbner 2010). Despite those restrictions there are a significant number of voluntary associations among Filipino migrants, some that originate in Saudi Arabia and others in the Philippines: many tend to include events and activities that are both locally and transnationally orientated. In Vora's (2013) terms those voluntary organizations are evidence of alternative forms of crafting belonging and exercising otherwise 'impossible citizenship'.

The Philippine Embassy had, up until the end of 2012, invited community organizations to register as 'partners' with the embassy in Saudi Arabia (Arab News, 15 May, 2003). In October, 2012, the Saudi government issued a circular to foreign embassies demanding that the latter, "prevent the creation and/or registration of community organizations' and 'cancel the formation of organizations and their activities without permit from the Saudi MFA [Ministry of Foreign Affairs]' (Philippine Embassy Riyadh, 10/12/2012). Prior to that there had been some 150 officially accredited organizations listed by the Philippine Embassy. ${ }^{1}$ It is not entirely clear what has happened to those organizations as the suspension took place after the period of fieldwork. The official embassy line is that, 'all Filipino community organizations [...] are illegal in Saudi Arabia' (Arab News Sunday 5 May 2013), but many remain operational as evidenced in recent activity on Facebook and in 
press reports. My focus here is on the gendered dimension of these organisations drawing on material pertaining at the time of field work.

Of the 135 accredited organizations in 2010 , seven were headed by women. The overwhelming gender imbalance in Saudi Arabia does not reflect the situation in the Philippines where, 'Female NGO executive directors outnumber their male counterparts. Among all aggregate staff of the NGO sample [...] women outnumbered men by a ratio of six to four (Jose 2011, 20).' Rather, the disproportionate leadership positions occupied by men in CSOs in Saudi Arabia are evidently explained by a social situation in which women's public participation is highly constrained. The gendered nature of CSOs in Saudi Arabia shapes also the sort of groups formed. While workers associations and hometown/provincially identified organizations together account for 43 of the 128 male headed organizations (35\%), sports associations, which are almost exclusively male, number $31(24 \%)$.

These groups are classed and gendered. Some fraternities and sports clubs, especially tennis associations, are comprised of educated middle class men. Workers voluntary associations tend to be oriented to working class men and differentiated from professional organizations. Hometown and provincial organizations draw on members across class lines as do some sporting associations, basketball especially. As detailed below, these organizations are important sites for the articulation of caring masculinities.

\section{Masculinity and the gendering of care among migrant men in Saudi Arabia.}

Migrant masculinity is primarily realized through work and the remittance of their earnings to family and loved ones. Whereas migrant women contend with perceptions that transnational mothering is problematic (Madianou 2012) and are forced to assert that 'sending dollars shows feelings' (D. McKay 2007), it is taken for granted that the remittances men send is the way that they demonstrate care. 
For migrant men whose wife and children live with them in Riyadh, there is a different dynamic. In general it is only middle class professionals who are entitled to apply for an accompanying visa for spouse and dependents (Johnson 2010). Men who were able to provide for their family and secure their physical proximity were seen as truly successful. That physical proximity can lead to alternative care arrangements, but often affirmed conventional gender patterns and ideals. The latter is reinforced in host society by the overt policing of boundaries between men's and women's spaces and by women's legal subordination as dependants under men's guardianship (Johnson and Wilcke 2015). In what follows I present three vignettes, the first of which may be taken as the majority situation, the second two more exceptional in that the men shared significant domestic and care giving responsibilities.

The first man I call Buddi works as a 'freelance' IT engineer and web designer. Buddi lives in Riyadh with his wife and their four children. Buddi neither defines himself as primary care giver nor does he share domestic responsibilities. He claims to lack the competencies required and sees his role as financially providing the best possible opportunities for his children. Buddi takes pride in his wife's career as a pharmacist, but her refusal to be a full time mother has meant that he has, at her insistence, reluctantly taken on the task of finding another 'woman' to be paid caregiver: previously they employed an irregular migrant Filipina.

I met other men who described themselves as sharing care in the home. Minimally that means acting as family driver ferrying family members to and from school, place of employment, shopping, friend's homes or religious activities. Women are not allowed to drive in Saudi Arabia, and while middle class Saudis employ migrant men as drivers, this is out of reach for middle class migrant Filipinos. For others, care giving extends beyond driving and acting as an escort. 
Albani is a driver for a wealthy Saudi family. His wife works as a nurse in a government hospital and they have a young child who lives with them in Riyadh. Albani gained the consent of his employer to work 'freelance' as a taxi driver, in exchange for a fixed fee paid each month to his employer to whom he is formally tied: freelancing enabled him to take shared responsibility for their child's care, act as family driver and maintain an independent source of income.

While Albani's willingness to take on caring responsibilities may be explained by the higher status accorded his wife's occupation, Datu'an is a successful middle class man who has embraced a primary care-giving role. A well dressed, articulate man, Datu'an was educated in Manila but has lived in Riyadh since 1979. He works as an accountant in a large Saudi firm. Datu'an is a convert to Islam and is married to a woman from Lanao, whom he met at a hospital in Riyadh. They have two daughters who attend an Arabic school. Datu'an recounted with pride how against the odds (as someone from outside of the Maranao community) he managed to woo his wife and persuade her father to accept his proposal.

Datu'an normally wakes before dawn. After prayers, he prepares breakfast and drops his daughters at school between $6.30-6.45$. He returns home to collect his wife who he drops off at hospital at 7.30 and then he goes to work. At $1 \mathrm{pm}$ he fetches his daughters from school and then picks up his wife at 4pm and ferries her to, and from, the Arabic and Quranic reading class that she attends in the evening. In between, he goes home and prepares food for the family and oversees his children's homework. Datu'an invests an enormous amount of time and energy caring for and facilitating his wife and daughter's lives - tending, feeding, fetching - work recounted in terms of love and devotion. Taking on the role of care giver neither overtly threatened his sense of masculinity, nor was it a self-consciously pro-feminist man challenging conventional masculine norms. Rather his quiet but assured masculinity was underpinned both by his youthful gallantry and by his middle class success - the apparent 
flexibility in his working hours that enables him to act as cook, caregiver and driver an unspoken indicator of his relatively senior and trusted position in employment.

\section{Affective labour and acts of solidarity}

While some men take on care giving responsibilities and do so in the language of love, the men who do this are in the minority. However, there is another sort of affective labour that migrant men perform that is informed by an ethics of care and that enlivens men's solidarity practices (Lynch 2007). As indicated above, there are a myriad number of more or less formal migrant associations in Saudi Arabia. Men routinely, though by no means exclusively, occupy public leadership roles in these organizations. Men's leadership roles are not simply that of care commanders though some of the work that is done, for example, raising money for the bahay kalinga (house of care) that houses domestic workers who have escaped from abusive employers or for charitable projects or causes back home is public facing and organizational. Rather, men are also involved in 'frontline' care work within those organizations, though the way that care work is undertaken is sometimes via identifiably masculine idioms and practices.

The following ethnographic vignettes are drawn from encounters with two men that Alicia Pingol and I got to know well during fieldwork in Saudi Arabia. In the preceding section, I gave an account of Buddi's attitudes towards and ways of dealing with primary care giving responsibilities. What I describe below is Buddi's care work outside of the home focusing on the work done in his role as an officer within WMOWA (Western Mindanao Overseas Workers Association). Despite the name, it is, as Buddi himself explained, an informal voluntary association and not a formal workers union that is proscribed by law. Named after a regional locale in the Philippines, the group is comprised of Filipinos who identify with the major 'Muslim' ethnic groups in that region. 
Because of Buddi's personal contacts with a sheikh in a local $d a$ 'wah centre, the group has exceptionally been able to organize their own madrassah and run training classes for migrants looking to enhance their IT skills. One of their main activities is organizing annual basketball league competitions. Filipino men are keen players and follow Filipino basketball leagues avidly via satellite. Local basketball tournaments provide a safe and shielded activity, away from government eyes who, or at least it was assumed, regarded it as an innocent pastime for migrant workers.

I not only heard stories about and viewed numerous photos of previous basketball tournaments but also spent an afternoon in the $45 \mathrm{C}$ midday sun watching four teams compete in the middle of a Riyadh suburb. What was evident from what I observed, borne out by what Buddi and his fellow basketball players also told me during informal conversations, was that the men were deeply competitive and took pride in good performances, their team uniforms and, if photo evidence was anything to go by, the trophies won.

However, the events also appeared and were reported to be generally good natured even while points and fouls were aggressively contested. The teams were comprised of men with a variable range of sporting prowess and physical fitness and men praised and cheered both the more and less able. They were also from across the class spectrum, from men who worked as waiters to men who were engineers, and ranged in age from men who were well into their fifties to younger men in their early twenties.

From Buddi's point of view organizing the basketball competition was not only an occasion for sociability, but also an important way that men were able to keep in contact and look out for each other, particularly those who worked in situations where work was hard and there were greater opportunities for employer abuse. Buddi said that basketball was particularly important for relative newcomers to Saudi Arabia. It was through the connections forged through basketball that one young man had been recently sheltered in another married 
migrant couple's home after he left his employer reportedly because the latter had failed to pay his wages on time.

This is affective labour that is both careful and intimate. Getting to basketball required cooperation and relied on more affluent migrants, i.e. those who could afford a car, to ferry those without. Routine text enquiries about basketball practice and matches served as appropriate vehicle for keeping a friendly, but not overtly prying or intrusive, look out for each other. Basketball also enables physical contact, not just of the aggressive sort: massaging cramped muscles and embracing sweaty teammates establishes a sensuous link with the bodily intimacies and interactions of male homosocialities in the Philippines. Moreover, while WMOWA was, by Buddi's own admission, a self selecting group on the basis of ethnicity and religion, it was not just the men's love of basketball that marked them as Pinoy (Filipino) but also the ethics of care which was talked about in the idiom of the mutual obligation of being kababayan, compatriots and fellow Filipinos. In Saudi Arabia in the absence of all but the most minimal of statutory obligations either on the part of the state that sent them and the host government that to all intents and purposes wants as little to do with them as possible, it is that sense of national solidarity that informs the routine acts of care giving among men in that place (see also Kathiravelu 2012).

But while acts of care and compassion are part of the acknowledged interdependencies of migrant men in diaspora, they also reinscribe social hierarchies of class and gender. First, offering a safe home to migrants, female domestic workers in particular, is often a way for middle class migrant men to meet the demand for domestic work in their home. Second, while migrant workers, female domestic workers in particular, often exhibit great personal courage and savvy in escaping from abusive employers, the men who assist women and men to find shelter if not alternate employment as irregular migrants are able to claim, rightly, that they too act courageously in ways that confirm and reframe masculine 
bravado as potentially sacrificial act of solidarity. Finally, being able both to organize and deliver practical assistance is the key to confirming one's relative standing, since it is premised on having the resources, as well as the ethical inclination, to do so. In that sense, while basketball is a practical vehicle for extending care and solidarity it also, more broadly, might be seen as a metaphor for the way that care and competition are inextricably interwoven in the bonds among men.

What I have described above I think captures at least one of the ways that migrant Filipino men in that diasporic situation craft dominant forms of masculinity, one that recalls what Thomas Kiefer (1973:114) described some time ago in relation to warriors celebrated in Tausug folklore who combined the ideals of the man of action and the man of piety and whose sacrificial actions condensed the arc of an ideal life course from youthful masculinity defined by care-less risk taking and adventure, to the more care-full life of householding father and pious elder (cf. K. Gardner 2002). Among Filipino men in the diaspora there is another idealized form of 'heroic' masculinity. As others have observed (S. McKay 2011) the notion of national sacrifice, originally gendered masculine and associated first with the early nationalist heroes, has more recently been taken up and extended by the Philippine state's construal of oversees workers as national heroes and if not wholly feminized, certainly extended to ideologically encompass female migrants as among the new national heroes (Rafael 2000). That idea of national sacrifice has to some extent been both re-appropriated back from the state - which is often felt to be impotent in protecting them - and also to some extent remasculinized.

Steven McKay (2011) writing about seafarers, for example, suggests that seafarers masculinize the discourse of passive endurance and compliance by foregrounding men's active pursuit of risk taking and adventure as a necessary part of being a migrant breadwinner. Certainly that notion of risk taking and adventure is a characteristic part of the 
way that men described their sojourns in Saudi Arabia, though that was also true for many migrant women, domestic workers especially, who routinely described their situation as a risk and gamble. What I highlight here is the way that in this context the action hero was defined through acts of sacrificial care of, for and about others: not just family and kin at home, but also and especially co-ethnics and fellow kababayans (compatriots) in diaspora.

The final vignette that illustrates this well is drawn from notes about another man, recorded by my late colleague Alicia Pingol, who was past president of another workers association in Riyadh, MKB (Mangagawang Kapit Bisig). Unlike Buddi, Lorrie was a Christian Filipino and occupied a working class position in Saudi Arabia, though through his leadership of the workers association he achieved recognition in the Filipino community across the class and religious divide. Alice described the tireless efforts of Lorrie to befriend and assist his compatriots (kababayaan) who were in need in that country, constantly on the phone answering calls from distressed migrants and helping them secure connections with people he thought might be able to help, as well as physically driving people from one place to another to access what services or assistance might be available, all the while doing so while he was in and out of hospital for renal failure and an acute heart condition:

'Light me a candle when you reach home. ' This is Lorrie's request for every kababayan (compatriot) he has assisted in obtaining an exit visa after rescuing her from an employer or from an indefinite stay in the Bahay Kalinga (house of care) run by the Philippine Embassy. Between the choices of going home to live his last years with his own family or staying in Saudi, his determined answer was, 'there are many kababayans here who need help.' Lorrie attained a deeper humanness among compatriots in KSA.

Volunteering as the father of the lost and oppressed, he was a much recognized leader by the Philippine Embassy in Riyadh. MKB is mentioned as the longest surviving and most active Filipino organization. While Lorrie did not elaborate how they returned to the Kingdom despite their deportation, I surmised that they must have the blessings of the highest officer responsible in exit and re-entries of foreign workers. Lorrie found himself of greater relevance to the Filipino community in Saudi, he persisted to find a way for his return. 
In the village of Lorrie and Evi, his wife, making a sacrifice if not whose very life is sacrificed is a meritorious act. And having devoted themselves to this role, they have readied their bodies to further tragedies, including dying in a foreign soil. Lorrie after all is still with compatriots from whom he has earned their esteem. To him, if no reward is at sight prayers and more lighted candles may offer some promise. (Pingol, n.d.)

In one of life's tragic coincidences, the sacrifice alluded to in the passage above did come to pass. Lorrie died in Saudi Arabia around the same time that Alice passed away in her home town in the Philippines, his death, and that of one of Lorries colleagues, reported in Arab News, an online English language daily:

Various Filipino groups in the Saudi capital expressed sadness yesterday over the death of two former community leaders who had rendered various services to compatriots while working in the Kingdom. [...] Bong Amora, OFW Congress secretary-general, also lamented 'the loss of two selfless ' community leaders. [He, (Lorrie)] was always there when the community needed help.[...] Robert Ramos, president of the Samahan ng mga Manggagawang Filipino ng Al Babtain (SAMAFIL), also expressed sadness. 'Their untimely death makes the heart sink. They were a tower of strength as far as helping the Filipino community is concerned. They were always around to lend a helping hand. ' (Arab News 12/03/2012, http://www.arabnews.com/node/408546)

If, as Bourdieu (1998) suggests, the obituary pages mark out the great and the good and confer the symbolic capital of social legitimacy - both on those who write them and the deceased who feature in them - then those words confirm that Lorrie was not just, to rephrase Herzfeld (1985), good at being a man, but a good man, his performative achievements as a good man continuing to circulate among and define the competitive bonds among that group of men and women who hold the effective, because affective, exercise of care, compassion and sacrifice in community service to be the cultural ideal of masculinity in that place. 


\section{Conclusion: masculinity, care and the 'gentle violence' of pastoral power.}

Foucault's $(2007,125)$ description of pastoral power as 'care over a flock in movement' acquires new meaning in a situation where migrants take on responsibilities for their own and other's care within, and out with, the protections of a 'masculinist state' (Young 2003). In Saudi Arabia political power is officially patriarchal and social relations organized according to the principles of benevolent patriarchy that installs men as the guardians of dependent women and children (Al-Rasheed 2013). Under the kafala system of sponsorship, migrants too formally fall under the protection of their sponsors who act as a proxy for the state. The gendered consequences of that for migrant women, domestic workers especially, whose daily life and working conditions are contingent on the beneficence of employers rather than guaranteed by law and enforced by the state, has been relatively well documented. In this article I focus on the impact of that gendered migration regime on the making of migrant men and masculinities and describe the ways that care for and about fellow migrants become central to manly ideals in ways that refigures rather than resists the logic of the 'masculinist state' that they are subject to as foreign men.

One dimension that remains implicit in Foucault's account and that migrant men's care practices disclose is that it is first and foremost an embodied practice. It is not watching from afar and organizing care at a distance, but rather intimate labour (Boris and Parreñas 2011:7). Above all, as Foucault does make explicit, it is a form of power whose aim is not status and glory but keeping safe and ensuring the well being of others for whom one assumes ethical responsibility. While status and recognition is conferred on good men, the logic of this cultural economy is such that status and recognition may only be achieved through practicing an ethics of care rather than through seeking honour and recognition. 
In that respect there are echoes here of Bourdieu, elsewhere writing about the 'gentle violence' of symbolic domination and the relation between dominant and subordinate men in Kabylia, when he says:

[T] he best way in which the master could serve his own interests was by working away, day in, day out, with constant care and attention, weaving the ethical and affective, as well as economic, bonds that tied his khammes (sharecropper) to him $(1990,127)[$.

The relation between master and sharecropper was not based on great disparities of wealth and resources (Bourdieu 1990, 127). Similarly it is the precariousness of middle class status and their material and, in the Saudi context, juridical proximity to working class compatriots in terms of their foreign resident status, which in some sense makes necessary the virtues of care (Johnson 2010). The relations between dominate and subordinate men does not in any way presuppose docility on the latter's part even when the authority of the former is 'exercised in the form of protective authority over those who entrust themselves to him (Benveniste 1973, 84ff, cited in Bourdieu 1990, 128)'. This is an agonistic relation in which men compete not over who is entitled to exercise authority, but who is willing and able to act as shepherd. In that model of hegemonic masculinity, pastoral power in Bourdieu's (1990, 128-9) terms 'requires those who exercise it to pay a personal price', and the personal price is in terms of expending themselves and their resources for the care of others.

Returning to the broader gendered and spatial dynamics of these processes it is necessary to recall that the public acts of social work and solidarity, that crucially involve embodied and affective labour, and the public recognition that those acts confer on those labours of love, often, though not always, still draws on the often unrecognized, because misrecognized, primary care giving work of women, whether that is looking after children and other dependants in home country or in Saudi Arabia, including irregular migrants sheltered in their homes. Pastoral power in that sense is a very specific form of what 
Jongwilaiwan and Thompson (2013) refer to as 'transnational patriarchy' in a situation where outwardly oriented 'caring' practices are not counterpoised to hegemonic masculinity but rather become the key marker and register of and for the most honoured forms of masculinity. In sum, the circumscription of migrant men's formal political participation and leadership, their daily experience of the humiliations of 'race', together with a gender regime that inhibits women's participation in CSOs in what is structurally one of the most overtly patriarchal situations, creates a situation that not only, as elsewhere, sometimes forcefully 'retraditionalizes' gender relations in ways unknown in the Philippines, but also paradoxically ensures that caring comes to be the dominant model of and for masculinity among migrant Filipino men and perhaps most especially for those who aspire to occupy leadership positions in that place.

\section{Acknowledgement}

The work presented in this article derives from the 'Footsteps' project on migrant and diasporan Filipinos (AHRC grant AH/E508790/1/APPID:123592). The article was first presented at the 'Transnationalism, Gender Hierarchies and Masculinity in Asia' Workshop at the Asia Research Institute, National University Singapore, 11-12 March, 2013 and completed while a visiting scholar in the Department of Anthropology, Stockholm University in 2014 funded by the Forum for Asian Studies. I am grateful for the comments of workshop participants and especially to Eric Thompson, Johan Lindquist, Ward Keeler and Shahram Khosravi. I remain indebted to my late colleague, Alicia Pingol.

\section{Notes:}

1. Philippine Embassy Advisory No. 190 - 2012 (http://riyadhpe.dfa.gov.ph/index.php/siteadministrator/advisories/203-host-govt-policy-on-the-formation-of-organizations). The list of Philippine Embassy Accredited Organizations that I draw on is from August 2010 and identifies some 135 accredited community organizations (https://www.facebook.com/notes/filipinos-insaudi-arabia/list-of-accredited-community-partner-philippine-embassyriyadh/147926435231255). 


\section{Notes on contributor}

Dr Mark Johnson is Reader in Social Anthropology at the University of Hull. He has conducted ethnographic research in the Philippines, Vietnam, Costa Rica and Saudi Arabia. His research is focused on gender and sexuality, movement and identity. Recent publications include Diasporic Journeys, Ritual, and Normativity among Asian Migrant Women (Routledge, 2011, with Pnina Werbner), 'Queer Asian Subjects: Transgressive Sexualities and Heteronormative Meanings' Asian Studies Review (2012 with Evelyn Blackwood, eds.) and 'Mediated Diasporas: Material Translation of the Philippines in a Globalized World' South East Asia Research (2011, with Deirdre McKay, eds)

\section{References}

Aguilar, Filomeno V. 1996. 'The dialectics of transnational shame and national identity. ' Philippine Sociological Review 44(1): 101-136.

Ahmad, Ali N. 2011. Masculinity, Sexuality, and Illegal Migration: Human Smuggling from Pakistan to Europe. Farnham: Ashgate.

Al-Rasheed, Madawi. 2013. A Most Masculine State: Gender, Politics and Religion in Saudi Arabia. Cambridge: Cambridge University Press.

Benveniste, Emile. 1973. Indo-European Language and Society. London: Faber.

Berg, Lawrence, and Robyn Longhurst. 2003. 'Placing Masculinities and Geography. ' Gender, Place and Culture 10 (4): 351-60.

Boris, Eileen and Rhacel Parreñas, eds. 2010. Intimate Labors: Cultures, Technologies and the Politics of Care. Stanford, CA: Stanford University Press.

Bourdieu, Pierre. 1990. The Logic of Practice. Translated by Richard Nice. Oxford: Polity Press.

Bourdieu, Pierre. 1998. The State Nobility: Elite Schools in the Field of Power Palo Alto: Stanford University Press.

Babül, Elif. 2015. 'The paradox of protection: Human rights, the masculinist state, and the moral economy of gratitude in Turkey '. American Ethnologist 42(1): 116-130.

Connell, R.W. and James W. Messerschmidt. 2005. 'Hegemonic Masculinity: Rethinking the Concept. ' Gender \& Society 19 (6): 829-859.

del Aguila, Ernesto V. 2013. Being a Man in a Transnational World: The Masculinity and Sexuality of Migration. London: Routledge. 
Doucet, Andrea 2006. Do Men Mother?: Fathering, Care, and Domestic Responsibility. Toronto: University of Toronto Press.

Elliot, Karla 2015. 'Caring Masculinities: Theorizing an Emerging Concept '. Men and Masculinities 1-20. DOI: 10.1177/1097184X15576203

Foucault, Michel. 2007. Security, Territory, Population. Basingstoke: Palgrave MacMillan.

Gardner, A. 2010. City of strangers: Gulf migration and the Indian community in Bahrain. Ithica: Cornell University Press.

Gardner, Katy. 2002. Age, narrative and migration: the life course and life histories of Bengali elders in London. Oxford: Berg Publishers.

Haile, Aster G., and Karin A. Siegmann. 2014. Masculinity at Work: Intersectionality and Identity Constructions of Migrant Domestic Workers in the Netherlands. In Migration, Gender and Social Justice, edited by Thanh-Dam Truong, Des Gasper and Jeff Handmaker, 105-119. Hexagon Series on Human 3 and Environmental Security and Peace 9, DOI 10.1007/978-3-642-28012-2_1

Hanlon, Niall. 2012. Masculinities, Care and Equality: identity and nurture in men's lives. Basingstoke: Palgrave MacMillan.

Herzfeld, Michael.1985. The Poetics of Manhood: Contest and Identity in a Greek Mountain Village. Princeton: Princeton University Press.

Inhorn, Marcia and Emily Wentzell. 2011. 'Embodying emergent masculinities: Men engaging with reproductive and sexual health technologies in the Middle East and Mexico. 'American Ethnologist 38(4): 801-815.

Jiwani, Yasmin. 2009. 'Helpless maidens and chivalrous knights: Afghan women in the Canadian press. ' University of Toronto Quarterly 78(2): 728-744.

Johnson, Mark. 2010. 'Diasporic Dreams, Middle Class Moralities and Migrant Domestic Workers among Muslim Filipinos in Saudi Arabia.' The Asia Pacific Journal of Anthropology. 11(3-4): 428-448.

Johnson, Mark and Pnina Werbner. 2010. 'Diasporic Encounters, Sacred Journeys: Ritual, Normativity and the Religious Imagination Among International Asian Migrant Women.' The Asia Pacific Journal of Anthropology 11(3-4): 205-208.

Johnson, Mark and Christoph Wilcke. 2015. Caged in and breaking loose: intimate labor, the state and migrant domestic workers in Saudi Arabia and other Arab countries. In Encountering the State: Intimate Labor Migrations across Asia, edited by Sara Friedman and Pardis Mahdavi, 178-211. Philadelphia: University of Pennsylvania Press. 
Jongwilaiwan, Rattana and Eric Thompson. 2013. 'Thai wives in Singapore and transnational patriarchy. ' Gender, Place \& Culture, 20(3): 363-381.

Jose, Lydia N. Yu. 2011. Civil Society Organizations in the Philippines, A Mapping and Strategic Assessment. Quezon City: Civil Society Resource Institute (CSRI).

Kandiyoti, Deniz. 1988. 'Bargaining with patriarchy. ' Gender \& society 2(3): 274-290.

Kathiravelu, Laavy. 2012. 'Social Networks in Dubai: Informal Solidarities in an Uncaring State. ' Journal of Intercultural Studies 33(1): 103-119.

Kiefer, Thomas. 1973. 'Parrang Sabbil: Ritual suicide among the Tausug of Jolo. ' Bijdragen tot de Taal-, Land- en Volkenkunde 129(1): 108-123.

Lynch, Kathleen. 2007. Love labour as a distinct and non-commodifiable form of care labour. Sociological Review 55(3): 550-570.

Lynch, Kathleen, John Baker, and Maureen Lyons. 2009. Affective Equality. Basingstoke: Palgrave Macmillan.

Lynch, Kathleen and Hanlon, Nial. 2011. 'Care-Free Masculinities in Ireland. ' In Men and Masculinities Around the World: Transforming Men's Practices, edited by Elisabetta Ruspini, Jeff Hearn, Bob Pease, and Keith Pringle, 45-58. Basingstoke: Palgrave MacMillan.

Madianou, Mirca. 2012. Migration and the accentuated ambivalence of motherhood: the role of ICTs in Filipino transnational families. Global Networks 12(3): 277-295.

Margold, Jane. 1995. 'Narratives of Masculinity and Transnational Migration. ' In Bewitching Women, Pious Men: Gender and Body Politics in Southeast Asia, edited by Aiwha Ong and Michael Peletz, 274-98. Berkeley: University of California Press.

Mcllwaine, Cathy. 2010. 'Migrant Machismos: exploring gender ideologies and practices among Latin American migrants in London from a multi-scalar perspective. ' Gender, Place and Culture 17(3): 281-300.

McIlwaine, Cathy and Anastasia Bermudez. 2011. 'The gendering of political and civic participation among Colombian migrants in London. ' Environment and Planning-Part A 43(7): $1499-1513$.

McKay, D. 2007. 'Sending Dollars Shows Feeling' - Emotions and Economies in Filipino Migration. ' Mobilities 2(2): 175-194.

McKay, Steven. 2007. 'Filipino Sea Men: Constructing Masculinities in an Ethnic Labour Niche. ' Journal of Ethnic and Migration Studies 33(4): 617-633.

McKay, Steven. 2011. Re-masculinizing the hero: Filipino migrant men and gender privilege. Singapore: Asia Research Institute (ARI). 
McKay, Steven, and Lucero-Prisno III, D. E. 2012. 'Masculinities afloat. In Men and masculinities in Southeast Asia. ' edited by Michele Ford and Lenore Lyons, 20 -37. London: Routledge.

Messner, Michael A. 2007. 'The masculinity of the governator: Muscle and compassion in American politics. ' Gender \& Society 21(4): 461-480.

Osella, Filippo and Caroline Osella. 2000. 'Migration, Money and Masculinity in Migration to the Gulf. ' Journal of the Royal Anthropological Institute (N.S.) 6: 117-133.

Osella, Filippo. 2012. Malabar Secrets: South Indian Muslim Men's (Homo)sociality across the Indian Ocean. Asian Studies Review 36(4): 531-549.

Pingol, Alicia. 2001. Remaking Masculinities: Identity, Power, and Gender Dynamics in Families with Migrant Wives and Househusbands. Diliman, Quezon City: University of the Philippines Press.

Rafael, Vicente. 2000. White Love and other Events in Filipino History. Durham, N.C., Duke University Press.

Robinson, Victoria, and Jenny L. Hockey. 2011. Masculinities in transition. Basingstoke: Palgrave Macmillan.

Stiehm, Judith. 1982. 'The Protected, the Protector, the Defender. ' Women's Studies International Forum 5(3/4):367-76.

Tarrant, Anna. 2013. 'Grandfathering as spatio-temporal practice: conceptualizing performances of ageing masculinities in contemporary familial carescapes. ' Social \& Cultural Geography, 14:2, 192-210

Vora, Neha. 2013. Impossible Citizens: Dubai's Indian Diaspora. Duke University Press.

Weiner, Myron. 1986. 'Labor Migrations as Incipient Diasporas. ' In Modern Diasporas in International Politics, edited by Gabriel Sheffer, 47-74. New York: St. Martin's Press. Young, Iris Marion. 2003. 'The logic of masculinist protection: Reflections on the current security state. 'Signs, 29(1): 1-25. 